\section{EMBRYRIDDLE \\ Aeronautical University}

SCHOLARLY COMMONS
Journal of Aviation/Aerospace

Education \& Research

Volume 25

Number 1 JAAER Fall 2015

Article 1

Fall 2015

\title{
A Meta-Analysis of Crew Resource Management/Incident Command Systems Implementation Studies in the Fire and Emergency Services
}

John C. Griffith

Embry-Riddle Aeronautical University, griff2ec@erau.edu

Donna L. Roberts

Embry-Riddle Aeronautical University, rober596@erau.edu

Ronald T. Wakeham Ph.D.

ERAU-WW, wakehamr@erau.edu

Follow this and additional works at: https://commons.erau.edu/jaaer

Part of the Business Administration, Management, and Operations Commons, Emergency and Disaster Management Commons, and the Other Education Commons

\section{Scholarly Commons Citation}

Griffith, J. C., Roberts, D. L., \& Wakeham, R. T. (2015). A Meta-Analysis of Crew Resource Management/ Incident Command Systems Implementation Studies in the Fire and Emergency Services. Journal of Aviation/Aerospace Education \& Research, 25(1). https://doi.org/10.15394/jaaer.2015.1647

This Article is brought to you for free and open access by the Journals at Scholarly Commons. It has been accepted for inclusion in Journal of Aviation/Aerospace Education \& Research by an authorized administrator of Scholarly Commons. For more information, please contact commons@erau.edu. 
The need for using participative leadership tools such as Crew Resource Management (CRM) evolved from an National Transportation Safety Board (NTSB) recommendation that followed United Airlines Flight 173 crash in 1978 (Jedick, 2014). National Aeronautics Space Administration (NASA), civilian and military aviation communities implemented CRM training to improve decision making during flight operations. Maintenance Resource Management (MRM) was a variant of CRM originating in the early 1990s with airlines such as U.S. Air (McKenna, 2002). CRM was adopted by the medical community in the 1990s, specifically in the surgical and nursing areas, to prevent untoward outcomes and infections (Sundar et al., 2007). Since the mid-1990s, fire and emergency services organizations began using CRM and Incident Command Systems training to reduce human error in firefighting and prehospital care (Lubnau \& Okray, 2001). This research focused on fire and emergency services studies to determine if CRM/Incident Command Systems training impact student retention of CRM concepts in a meaningful way. Meta-analysis statistical procedures were used to determine effect sizes (standardized mean differences) and levels of heterogeneity between the studies.

\section{Significance}

Lubnau and Okray (2001) argue that the idea that "Only the lead dog has a good view" is no longer acceptable in the fire service (p. 8). They further argue that leaders should use the entire team's skills. Citing the sentinel event of the 1994 Storm King Mountain fire where 14 fire fighters perished as a catalyst, the fire service needs to build on the CRM training successes enjoyed by aviation and medical communities. Nineteen years later, similar calls for improving firefighter CRM went out after the Yarnell fire killed 19 firefighters (Leschak, 2013). The number of fires from 2002 through 2013 have decreased from 1.68 million to 1.24 million. Firefighters have responded to 447,500 fewer fires (National Fire Protection Association 
[NFPA], 2014). Firefighter deaths have averaged approximately 87 per year showing a steady decline over the 12 year period, yet there is a weak correlation between number of fires and firefighter deaths $(\mathrm{r}=.464, \mathrm{p}=.128)$. Approximately $78 \%$ of the variation between number of fires and fire fighter deaths cannot be explained simply by the number of fires. Any tool that can improve decision-making and reduce error needs to be considered (Wakeham \& Griffith, 2015).

\section{Problem Statement}

The problem examined is to determine if CRM training enhances student retention of CRM principles. The authors chose to do a meta-analysis to examine this problem.

\section{Literature Review}

\section{CRM - History, Origins and Applications}

Crew Resource Management (CRM) has been comprehensively defined as; A flexible, systemic method for optimizing human performance in general, and increasing safety in particular, by (1) recognizing the inherent human factors that cause errors and the reluctance to report them, (2) recognizing that in complex, high risk endeavors, teams rather than individuals are the most effective fundamental operating units and (3) cultivating and instilling customized, sustainable and team-based tools and practices that effectively use all available resources to reduce the adverse impacts of those human factors (Marshall, 2009, p. 22).

Though common jargon in today's managerial environments, crew resource management, initially more narrowly referred to as flightdeck or cockpit resource management, formally began with an NTSB recommendation made during their investigation of the 1978 
United Airlines Flight 173 crash. In that disaster a DC-8 crew ran out of fuel over Portland, Oregon while troubleshooting landing gear malfunction. The NTSB concluded that the crash was ultimately caused by poor team communication and the captain's failure to accept input from junior crew members combined with a lack of assertiveness by the flight engineer (Jedick, 2014).

From these conclusions, the NTSB made several recommendations in their report, including;

Issue an operations bulletin to all air carrier operations inspectors directing them to urge their assigned operators to ensure that their flightcrews are indoctrinated in principles of flightdeck resource management, with particular emphasis on the merits of participative management for captains and assertiveness training for other cockpit crewmembers (National Transportation Safety Board [NTSB], 1978, Class II, Priority Action X-79-17).

In essence, crew resource management is a more focused and specific application of the broader concept of participative management, which grew out of the human relations movement and gained momentum through the 1960s and 1970s. Advocates of participatory management practices challenged the traditional organizational hierarchies, authoritarian systems and rigid division of labor. While this form of leadership style was acknowledged across various industries and workplace settings for empowering employees and increasing loyalty and motivation, the NTSB recognized its more crucial role in emergency situations where it could play a part in the prevention of and/or reaction during disasters, thus potentially saving lives.

After the NTSB recommendations were published, CRM training was first adopted by United Airlines in 1981 and subsequently has become a mandatory part of crew training for most 
major airlines, NASA and military aviation (Jedick, 2014; Marshall, 2009). In its early application, CRM training focused primarily on pilots and the immediate cockpit environment. However, with verification of its efficacy throughout the 1990s, it was extended to flight attendants and maintenance technicians, and finally for all aviation personnel (Helmreich, Merritt, \& Wilhelm, 1999).

MRM refers to CRM as specifically applied in an aircraft maintenance setting. Just as CRM emerged from the analysis of a preventable aviation accident, a similar mishap led to the development of MRM and maintenance-based human factors training. In 1988, Aloha Airlines Flight 243 suffered a near-catastrophic failure. The subsequent investigation identified various human-factors-related problems leading to the failed inspections that were determined to be the main cause of the mishap. These findings highlighted maintenance activities as potential accident causal factors, and thus led to the development and implementation of MRM training (Sian, Robertson, \& Watson, 1998). The first documented governmental regulation for standardized MRM training appeared in the Advisory Circular 120-72, Maintenance Resource Management Training in September, 2000.

In keeping with the basic tenets of CRM, MRM training emphasizes a team approach to human error reduction using principles that seek to improve communications, situational awareness, problem solving, decision making, and teamwork. MRM advocates a decentralized, human-centric approach to safety and encourages work teams to communicate vital operational risk and safety information directly and informally, regardless of rank or position, thus permitting rapid response to prevent impending crises (McKenna, 2002, Taylor, 1998).

Since its inception as a reaction to the NTSB recommendations, the role of CRM in enhancing teamwork, and thus safety, has been widely accepted (Salas, Burke, Bowers, \& 
Wilson, 2001; Salas, Rhodenizer, \& Bowers, 2000). Marshall (2009) observed, “CRM training, coupled with consistent and routine error and incident reporting, has helped transform commercial aviation into a model of high reliability, now operating well beyond a level of Six Sigma quality and safety" (p. 6). Marshall further noted the usefulness of applying CRM to medical settings, indicating, "It took a landmark tragedy to indelibly imprint the lesson of human fallibility and rouse of revolution in aviation safety that is now spreading to health care" (2009, p. 5).

Marshall goes on to iterate the applicability of CRM systems in various medical settings, stating; Aviation and health care have much in common. Both fields are extremely complex, requiring that highly trained personnel function ably under considerable stress. In both, human beings are entrusted with the safety of others, and the available literature is replete with evidence that human factors cause the vast majority of harmful mistakes (Marshall, 2009, p. 7).

Empirically, Sexton, Thomas, and Helmreich (2000) compared flight crews with operating room personnel on several CRM-related measures, including attitudes and practices involving teamwork. This landmark study, conducted over a 15 -year period, included more than 30,000 cockpit crew members (captains, first officers, and second officers) and 1,033 operating room personnel (attending surgeons, attending anesthesiologists, surgical residents, anesthesia residents, surgical nurses, and anesthesia nurses). Sexton and colleagues concluded that safetyrelated behaviors that have been applied and studied extensively in the aviation industry are also relevant in health care. Various other researchers (Gaba, Howard, Fish, Smith, \& Sowb, 2001; Howard, Gaba, Fish, Yang, \& Sarnquist, 1992; Risser et al., 1999; \& Shortell et al., 1994) 
reached similar conclusions on the relative applicability of CRM training approaches in medical context where human factors play a large role.

\section{CRM in Emergency Services}

As with the aforementioned medical environments, similarities exist between crew interaction in aviation settings (particularly in response to emergency situations) and the interactions of emergency service crews. Specifically, the following comparisons can be drawn:

1) Both crews are structured with a leader and one or more crew members; 2) The group functions best when it works as a cohesive team; 3) The team can spend hours of time performing mundane activities and then be called upon to act swiftly under stressful conditions; and 4) Some crews work together frequently and others are assembled on short notice (Tippett, 2009). Additionally, as in aviation and medical emergency situations, factors such as severe time pressure, personal danger, loud noise, multiple distractions and a confusing and dynamically changing environment further complicate the situation and exacerbate the need for effective and efficient teamwork (LeSage, Dyar, \& Evans, 2011).

Furthermore, like in aviation, communication failures, poor decision making, lack of situational awareness, poor task allocation and leadership failures are listed as the contributing factors in far too many National Institute of Occupational Safety and Health (NIOSH) Firefighter Line-of-Duty Death Reports (International Association of Fire Chiefs [IAFC], 2005). Despite advances in fire service equipment, standards and education that have substantially reduced the number of fires and enhanced the firefighters' ability to contain fires, death and injury rates have plateaued over the last two decades (Okray \& Lubnau, 2004). Veterans in the emergency service field have argued strongly for the implementation of CRM to fill the gaps in technical based 
safety training programs by including the human aspect of situations thereby potentially reducing these stagnant death and injury rates. Specifically, Lubnau and Okray (2001) argue;

The fire service now finds these proven concepts knocking at its door. Equipment is becoming more and more reliable. Firefighting techniques and strategies are becoming scientifically honed, and new technologies for firefighter safety are being brought to the market daily. At the same time, firefighter fatalities and injuries on the emergency scene have plateaued.... The time has come for these aviation principles to be adopted by the fire service. However, for that to happen, a whole new mind set and organizational culture will need to be instilled from the top down. Modifying an organization's leadership style from military and authoritarian to team leadership takes extensive training and a courageous release of control by those in command.... The fire service needs to take on a new and tried approach that takes advantage of the entire team's skills and senses, not just those of the leader. Leaders must buy into the concepts of CRM completely if these principles are to be successfully adopted (p. 8).

From existing CRM models, training programs for the fire and emergency services (often referred to as Team Resource Management - TRM) have been adapted to focus on basic skills and attitudes including communications, situational awareness, problem solving, decision making, and teamwork (Hagemann, Kluge, \& Greve, 2012). The goal of CRM/TRM programs is to enable emergency service teams to make the right decisions in the field quickly, safely, and 
collegially. As such, its principles stress the necessity of both having strong leadership in place to guide a crew's decision-making process, while encouraging individual team members to share critical information to support the team leader in making the crucial decisions during an emergency. Specifically, the CRM/TRM process works to break down common communication barriers by focusing on the team as a whole with a common goal using the following six steps: 1) Using inquiry to evaluate procedure; 2) Using advocacy to respectfully question authority; 3 ) Using conflict resolution techniques to learn from errors; 4) Using strong leadership to make group decisions; 5) Observing and critiquing team decisions to meet mission goals; and 6) Fostering an open and accepting team environment, where members discuss options for team improvement (LeSage, Dyar, \& Evans, 2011).

\section{CRM/TRM Program Evaluation}

Evaluation of the effectiveness of prevention based training programs is, by nature, inherently difficult, as measuring what one has prevented is not generally feasible beyond 'what if' conjecture. However, its merit in the aviation industry is virtually unquestioned, to the extent that it has become standard mandatory aspect of safety training at all levels. Empirically speaking, throughout its deployment across the diverse fields, various studies have found positive results using the criteria of reactions, attitudes, knowledge acquisition, and behaviors (Fisher, Phillips, \& Mather, 2000; Helmreich \& Foushee, 1993; Helmreich \& Wilhelm, 1991;

O’Connor et al., 2008; Salas, Prince et al., 1999; Salas, Wilson, Burke, \& Wightman, 2006). Furthermore, it is generally assumed that positive changes in knowledge - i.e., cognitive level and attitudes - i.e., affective levels - are important precursors for changes in safety-relevant behavior (O'Connor et al., 2008). 
Salas, Burke, Bowers, and Wilson (2001) and Salas et al. (2006) reviewed numerous studies, which demonstrated that CRM/TRM training had a positive impact on the team members' reactions and their subjectively rated learning success as well as on their declarative knowledge acquisition (O'Connor, Flin, Fletcher, \& Hemsley, 2002; Salas, Fowlkes, Stout, Milanovich, \& Prince, 1999). Additionally, the CRM/TRM training was shown to have a positive impact on teamwork-relevant attitudes (Gregorich, Helmreich, \& Wilhelm, 1990; Helmreich \& Wilhelm, 1991). As the implementation of CRM/TRM programs gain wider acceptance throughout the Emergency Services field, more empirical studies will be necessary to help tailor program outcomes and delivery modes for specific contexts as well as to provide an overall evaluation of its relative applicability and effectiveness.

\section{Literature Summary}

CRM has a strong and solid history as a method for the effective management of teams and can have particular application in areas where optimal team functioning is necessary in high stress situations. Based upon its continuing success, new fields continually embrace its core concepts and modify its application to their specific contexts. In the fire and emergency services fields, CRM/TRM continues to gain support as a means of implementing a new philosophy of participative management (Lubnau \& Okray, 2001). As evidence of this, in March of 2015 the Regional Alliance for Firefighting Training will host the First Annual Crew Resource Management National Symposium based on fostering awareness and application of CRM and "a commitment to change fire and emergency service leadership and operating cultures that have evolved over generations of time” (Regional Alliance, 2015, para. 1).

If current trends were to continue, over the next decade approximately 1,000 fire fighters would die and one million would be injured. Combined with comprehensive technical training 
and skill building programs, CRM can enhance a team's ability to respond in a coordinated and cooperative manner that utilizes the strengths of each member. In emergency services contexts this can equate to saving lives.

\section{Methods}

\section{Study Selection}

An argument presented in this paper is that there are few Crew Resource Management (CRM)/Incident Command System studies in the fire service with quantified results. An electronic search was conducted using ProQuest database, and general internet searches for previous studies. Because of the transition of the U.S. fire service to a broader emergency services scope, the search was widened to incorporate emergency medical services as well as fire studies. Three studies (four sets of results) were identified for inclusion in the statistical metaanalysis comparison. These studies all included some form of testing to determine improvement in CRM concepts after training was provided and presented quantitative statistical results using appropriate statistical analysis.

Glow, Colucci, Allington, Noonan, and Hall (2013) studied medical preparedness in rural settings. Their study involved hospital and pre-hospital Fire and Emergency Medical Technicians (EMT) pre-hospital staff in the areas of communication, incident command systems and triage. A group of 175 were offered a one day training session which included two exercises and four one hour blocks of didactic instruction. The pre and posttests had 18 questions. The authors noted that fire personnel exhibited higher baseline test scores than any other group, but that all groups showed improvement after the training. Glow et al. (2013) compared their data using a one way analysis of variance due to multiple professional groups in the study. The authors noted that "the participants volunteered for training so selection bias could not be ruled 
out” (p. 340). Another weakness noted was the design which had no control group. The results of 70 firefighter and EMS personnel were used for the Meta-analysis.

Fisher, Phillips, and Mather (2000) conducted a study to determine if CRM could play a positive role in reducing medical accidents. The study focused on civilian medical aircrew and was a posttest only control group design. Subjects were randomly selected for a survey. Based on their responses, they were placed in the control (not trained) or treatment (CRM trained - all three sessions) group. The survey had 15 questions specifically assessing CRM concepts and was patterned after a survey used by the NASA Ames Research Center. Responses from 144 surveys were evaluated. Eight people had not received training, 58 air crew had received all three modules of CRM training. The remaining surveys were not used in their comparison. Scores for the control and treatment groups were evaluated using a $t$-test for independent samples yielding positive results $(\mathrm{p}=.031)$. All subject scores were used in the meta-analysis.

Hagemann, Kluge, and Greve (2012) studied the effects of CRM training in the fire service. This German study compared three different groups of scores; a pretest, posttest one day after training and a posttest 7 months after CRM training. The training was one-half day. CRM knowledge was significantly higher at one day and 7 months post training than prior to training. The authors noted however, that there was a significant decrease in CRM knowledge 7 months post training. Data were reported as paired t-test results between the pre-test score and either the one day or 7-month post training score. Findings showed significant improvement to CRM knowledge to the $\mathrm{p}<.001$ for 1 day $(\mathrm{n}=28)$ post training and $\mathrm{p}=.001$ for 7 months $(\mathrm{n}=$ 11) post training. The data for overall knowledge (compilation of 5 different elements of CRM to include shared mental models, communication, situational awareness, team competencies and feedback) were used in the meta-analysis. 
The researchers excluded studies that did not have some form of assessment test for CRM improvement. Several studies indicated that CRM had been implemented with no results reported on trainees' grasp of CRM concepts. Additionally, CRM studies in other high risk occupations were excluded (such as oil rigs) because it was determined that the job settings were too different than what would be experienced in the fire and EMS settings.

Possible publication bias could exist with these results since those who implement training programs would be more likely to report and publish outcomes that were successful. It is important to acknowledge this potential bias and use conservative measures when reporting meta-analysis results (Gay, Mills, \& Airasian, 2006).

\section{Treatment of the Data}

Four sets of study results in the fire and emergency services were analyzed using metaanalysis statistical tools. A continuous measure statistic (difference of means divided by the pooled standard deviation) was used to calculate the standardized mean difference (effect size). In this study, the Hedges $\mathrm{g}$ formula was used to express the standardized mean difference with a correction for small sample sizes (DerSimonian \& Laird, 1986; MedCalc, 2014a).

The researchers used MedCalc version 14 software to calculate $\mathrm{p}$ values for both the fixed and random effects models. The studies evaluated were statistically weighted based primarily on their sample sizes (MedCalc, 2014b). The random effects model assumes that the true effects vary between studies and generally gives a more conservative estimate of the common effect size (Borenstein, Hedges, Higgins, \& Rothstein, 2009). The researchers would suggest that the random effects model is the most effective way to evaluate these data due to the different teaching and testing methods used in the studies. 
Heterogeneity measures how much variation, not due to random chance, between groups of studies. Cochran's Q and the $\mathrm{I}^{2}$ statistic were used to evaluate the possible heterogeneity between the studies. Regarding interpretation of the Q statistic, Higgins, Thompson, Deeks, and Altman (2003) suggested a value of 0.10 as a cutoff for significance. A Q result lower than 0.10 would indicate significant heterogeneity. Higgins et al. (2003) also suggest that the $\mathrm{I}^{2}$ statistic is a good indicator of the percentage of variation between studies. The higher the percentage, the more variation or heterogeneity between studies. $\mathrm{I}^{2}$ has a scale from $0 \%$ to $100 \%$ offering simple interpretation as well as comparability between the results of two or more meta-analysis studies.

\section{Results}

Table 1 shows a summary of the studies included in the meta-analysis. The aggregate number of test results examined was 283. Three of the four sets of results used a one-group pretest-posttest design. All of the studies included assessment testing on CRM concepts showing statistically significant positive results. A summary of study design, sample sizes, intervention and outcomes follows. 
Table 1

Summary of Studies Included in the Meta-Analysis

\begin{tabular}{|c|c|c|c|c|}
\hline Study & Design & $\begin{array}{l}\text { Sample } \\
\text { test } \\
\text { results }\end{array}$ & Intervention & Outcomes \\
\hline $\begin{array}{l}\text { Glow et al. (2013) } \\
\text { Fire fighters } \\
\text { /prehospital EMS }\end{array}$ & $\begin{array}{l}\text { One-group pretest-posttest } \\
\text { design. Scores of CRM } \\
\text { trained }(\mathrm{n}=68) \text { vs scores } \\
\text { prior to training }(\mathrm{n}=70) \text {. }\end{array}$ & 138 & $\begin{array}{l}\text { Crew Resource } \\
\text { Management } \\
\text { training course }\end{array}$ & $\mathrm{p}<.001$ \\
\hline $\begin{array}{l}\text { Fisher et al. (2000) } \\
\text { Aeromedical } \\
\text { Aircrew }\end{array}$ & $\begin{array}{l}\text { Posttest only control group } \\
\text { design. Scores of CRM } \\
\text { trained }(n=59) \text { vs those } \\
\text { who were not trained }(n= \\
8) .\end{array}$ & 67 & $\begin{array}{l}\text { Crew Resource } \\
\text { Management } \\
\text { Training course }\end{array}$ & $\mathrm{p}=.031$ \\
\hline $\begin{array}{l}\text { Hagemann et al. } \\
\text { (2012) Fire fighters } \\
\text { (1 day after } \\
\text { training) }\end{array}$ & $\begin{array}{l}\text { One group pretest-posttest } \\
\text { design. Group tested } \\
\text { before CRM training and } \\
\text { one month after training. }\end{array}$ & 56 & $\begin{array}{l}\text { CRM } 1 / 2 \text { day } \\
\text { training session }\end{array}$ & $\mathrm{p}<.001$ \\
\hline $\begin{array}{l}\text { Hagemann et al. } \\
\text { (2012) Fire fighters } \\
\text { (7 months after } \\
\text { training) }\end{array}$ & $\begin{array}{l}\text { One group pretest-posttest } \\
\text { design. Pre training and } 7 \text { - } \\
\text { month post training scores } \\
\text { compared. }\end{array}$ & 22 & $\begin{array}{l}\text { CRM } 1 / 2 \text { day } \\
\text { training session }\end{array}$ & $\mathrm{P}=.001$ \\
\hline
\end{tabular}

Note. Adapted from "Does crew resource management training work?" by J. Fisher, E. Phillips, and J. Mather, 2000, Air Medical Journal, 19(4), 137-139. "Managing multiple-casualty incidents: A rural medical preparedness training assessment," by S. Glow, V. Colucci, D. Allington, C. Noonan, and E. Hall, 2013, Prehospital and Disaster Medicine, 28(4), 334-341. "Measuring the effects of team resource management training for the fire service," by V. Hagemann, A. Kluge and J. Greve, 2012, Proceedings of the Human Factors and Ergonomics Society Annual Meeting, 56, 2442-2446.

Data were analyzed using MedCalc version 14 software (2014b). The confidence intervals are all positive meaning that the studies showed significant results. The total fixed and random effects models showed a significance level of $p<.001$. The fixed model showed a Standardized Mean Difference of 1.62. The Random Effects model was 1.726. Details are shown in Table 2. 
Table 2

Meta-Analysis Results

\begin{tabular}{lccccc}
\hline Study & Total & SMD & 95\% CI & t & p \\
\hline $\begin{array}{l}\text { Glow et al. (2013) EMS and } \\
\text { Firefighters }\end{array}$ & 138 & 1.445 & 1.068 to 1.821 & & \\
$\begin{array}{l}\text { Fisher et al. (2000) } \\
\text { Aeromedical Aircrew }\end{array}$ & 67 & 1.139 & 0.370 to 1.909 & \\
$\begin{array}{l}\text { 1 day Hagemann et al. (2012) } \\
\text { Firefighters }\end{array}$ & 56 & 2.918 & 2.153 to 3.683 & & \\
$\begin{array}{l}\text { 7-mo Hagemann et al. (2012) } \\
\text { Firefighters }\end{array}$ & 22 & 1.435 & 0.468 to 2.402 & & \\
& & & & & \\
Total (fixed effects) & 283 & 1.620 & 1.329 to 1.910 & 10.969 & $<0.001$ \\
& 283 & 1.726 & 1.000 to 2.452 & 4.678 & $<0.001$ \\
\hline \begin{tabular}{l} 
Total (random effects) \\
\hline
\end{tabular}
\end{tabular}

Note. Data calculated using MedCalc version 14 software, Meta-Analysis Continuous Test. Standardized Mean Difference (effect size) was calculated using the Hedges g statistic. Standardized mean differences greater than .8 indicate a large effect size (MedCalc, 2014b).

The results indicate that there is significant agreement between these studies regarding improvement in CRM concepts based on the standard mean differences. All exhibited large effect sizes. The fixed and random effects models also showed similar large standard mean differences. The forest plot showing the $95 \%$ confidence intervals of the standardized mean differences, fixed effects and random effects models is shown in Figure 1. 
Glow et al. (2013) EMS and Firefighters Fisher et al. (2000) Aeromedical Aircrew 1 Day Hagemann et al. (2012) Firefighters 7 Mo Hagemann et al. (2012) Firefighters Total (fixed effects) Total (random effects)

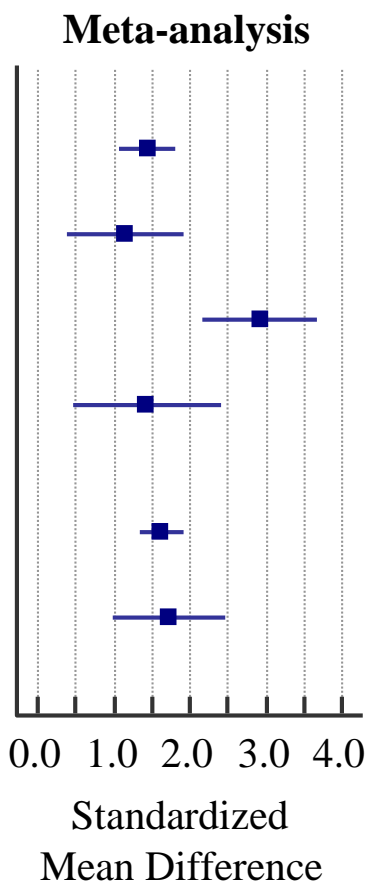

Figure 1. Forest plot showing 95\% confidence intervals of standardized mean differences (MedCalc, 2014b).

\section{Test of Heterogeneity}

The data were also analyzed for heterogeneity. The evaluation yielded a significant $\mathrm{Q}$ value of 14.143 ( 3 degrees of freedom, $\mathrm{p}=.0027$ ). The $\mathrm{I}^{2}$ statistic indicated a $78.79 \%$ inconsistency level that is not due to random chance. The $95 \%$ confidence interval for $\mathrm{I}^{2}$ was 43.14 to 92.09 (MedCalc, 2014b). There was a high level of variation in these results probably based on different intensity of training sessions and different testing methods to assess student acquisition of CRM concepts.

\section{Conclusions}

The data indicate that the standardized mean differences of the four sets of study results show a statistically significant positive effect of the CRM training $(\mathrm{p}<.001)$. These results support the argument for CRM training in the fire service. Additionally, there was a significant 
amount of heterogeneity between the studies as the $\mathrm{I}^{2}$ statistic indicated that $78.79 \%$ of the variation was not due to random chance. The high level of heterogeneity is not surprising due to the different training courses and testing methods used in the studies compared in the metaanalysis.

One difference noted in the Hagemann et al. study was the decline of CRM knowledge between 1 day after training and 7 months after training. Student scores dropped 13 points $(\mathrm{p}<$ .001). This result supports the need for continuous training. "The implication is that recurrent TRM (CRM) training is also needed, for example, in fire service teams and has to be developed and applied in practice" (Hagemann et al., 2012, p. 2446).

The difficulty in any meta-analysis is to identify studies with similar methodologies that report results using quantitative data. Some studies were excluded because they did not test for CRM concept retention by students. Additionally, possible publication bias may exist since authors are more likely to publish if they can show positive results of training programs. It can also be argued that any tool such as CRM that enhances decision-making and reduces mistakes merits consideration. The results of this meta-analysis support the idea of CRM in the fire service.

\section{Recommendations for Further Research}

The first four recommendations come directly from authors of the studies used in the meta-analysis:

1. Interdisciplinary training consisting of interdisciplinary didactic and functional exercise training can result in improved competence of emergency services personnel. This training should be conducted periodically (Glow et al., 2013). 
2. Ongoing training should be tailored to specific professional disciplines (Glow et al., 2013).

3. CRM training has shown to be effective. Leadership needs to create a continuing culture of CRM principles (Fisher et al., 2000).

4. There is a need not only for initial CRM training, but recurrent CRM training as well (Hagemann et al., 2012).

5. Future studies should not just focus on if CRM training was implemented in a fire station, but focus on the outcome of the training through testing.

6. Researchers should continue to evaluate the effectiveness of initial and recurring CRM training.

7. Future research should include case studies of successful uses of CRM/TRM in emergency response situations. Case studies (qualitative or quantitative) can yield useful data from emergency situations that can pinpoint if CRM was used and to what extent.

8. Sample student interview questions found in the Appendix should be used as a starting point to assess retention, strengths, and weaknesses in CRM Training programs. 


\section{References}

Borenstein, M., Hedges, L., Higgins, J., \& Rothstein, R. (2009). Introduction to meta-analysis. Chichester, United Kingdom: Wiley. http://dx.doi.org/10.1002/9780470743386

DerSimonian, R., \& Laird, N. (1986). Meta-analysis in clinical trials. Controlled Clinical Trials, 7, 177-188. http://dx.doi.org/10.1016/0197-2456(86)90046-2

Fisher, J., Phillips, E., \& Mather, J. (2000). Does crew resource management training work? Air Medical Journal, 19(4), 137-139. http://dx.doi.org/10.1016/S1067-991X(00)90006-3

Gaba, D. M., Howard, S. K., Fish, K. J., Smith, B. E., \& Sowb, Y. A. (2001, June). Simulationbased training in anesthesia crisis resource management (ACRM): A decade of experience. Simulation \& Gaming, 32(2), 175-195. Sage Publications, Inc. http://dx.doi.org/10.1177/104687810103200206

Gay, L. R., Mills, G. E., \& Airasian, P. W. (2006). Educational research: Competencies for analysis and application (8th ed.). New Jersey: Pearson Education.

Glow, S., Colucci, V., Allington, D., Noonan, C., \& Hall, E. (2013, August). Managing multiplecasualty incidents: A rural medical preparedness training assessment. Prehospital and Disaster Medicine, 28(4), 334-341. http://dx.doi.org/10.1017/S1049023X13000423

Gregorich, S. E., Helmreich, R. L., \& Wilhelm, J. A. (1990). The structure of cockpit management attitudes. Journal of Applied Psychology, 75(6), 682-690. http://dx.doi.org/10.1037/0021-9010.75.6.682

Halbesleben, J. R. B., Cox, K. R., \& Hall, L. (2011). Transfer of crew resource management training. Leadership in the Health Services, 24(1), 19-28. Bradford, United Kingdom: Emerald Group Publishing Limited. http://dx.doi.org/10.1108/17511871111102508 
Hagemann, V., Kluge, A., \& Greve, J. (2012). Measuring the effects of team resource management training for the fire service. Proceedings of the Human Factors and Ergonomics Society Annual Meeting, USA, 56(1), 2442-2446. http://dx.doi.org/10.1177/1071181312561497

Helmreich, R. L., \& Foushee, H. C. (1993). Why Crew Resource Management? Empirical and theoretical bases of human factors training in aviation. In E. Wiener, B. Kanki, \& R. Helmreich (Eds.), Cockpit Resource Management (pp. 3-45). San Diego, CA: Academic Press.

Helmreich, R. L., Merritt, A. C., \& Wilhelm, J. A. (1999). The evolution of crew resource management training in commercial aviation. The International Journal of Aviation Psychology, 9, 19-32. http://dx.doi.org/10.1207/s15327108ijap0901_2

Helmreich, R. L., \& Wilhelm, J. A. (1991). Outcomes of crew resource management training. International Journal of Aviation Psychology, 1(4), 287-300. http://dx.doi.org/10.1207/s15327108ijap0104_3

Higgins, J., Thompson, S., Deeks, J., \& Altman, D. (2003). Measuring inconsistency in metaanalyses. British Medical Journal, 327, 557-560. http://dx.doi.org/10.1136/bmj.327.7414.557

Howard, S. K., Gaba, D. M., Fish, K. J., Yang, G., \& Sarnquist, F. H. (1992). Anesthesia crisis resource management training: teaching anesthesiologists to handle critical incidents. Aviation Space Environmental Medicine, 63(9), 763-770.

International Association of Fire Chiefs (IAFC). (2005). Crew resource management manual. Fairfax, VA: IAFC. 
Jedick, R. (2014). United Airlines 173 - The need for CRM. Go Flight Medicine. Retrieved from http://goflightmedicine.com/united-airlines-173/

LeSage, P., Dyar, J. T., \& Evans, B. (2011). Crew resources management: Principles and practice. Sudbury, MA: Jones \& Bartlett Learning.

Leschak, P. (2013, July 13). Deadly Arizona fire: What will we learn? StarTribune. Retrieved from http://www.startribune.com/opinion/commentaries/215309681.html

Lubnau II, T., \& Okray, R. (2001, August 1). Crew resource management for the fire service. Fire Engineering. Retrieved from http://www.fireengineering.com/articles/print/volume154/issue-8/features/crew-resource-management-for-the-fire-service.html

Marshall, D. (2009). Crew resource management: From patient safety to high reliability. Centennial, CO: Safer Healthcare.

McKenna, J. T. (2002, October). Maintenance resource management programs provide tools for reducing human error. Flight Safety Digest, 21(10), 1-15. Retrieved from http://flightsafety.org/fsd/fsd_oct02.pdf

MedCalc. (2014a). Meta-analysis: Continuous measure. Retrieved from http://www.medcalc.org/manual/meta-analysis-continuousmeasure.php

MedCalc (Version 14) [Computer software]. (2014b). Belgium.

National Fire Protection Association (NFPA). (2014). Firefighter activities, injuries and deaths. Retrieved from http://www.nfpa.org/research/reports-and-statistics/the-fireservice/fatalities-and-injuries/firefighter-activities-injuries-and-deaths

National Transportation Safety Board (NTSB). (1978). United Airlines, Inc. McDonnell-Douglas DC-8-61, N8082U Portland, Oregon: December 28, 1978. NTSB. 9 (15/64). 
O'Connor, P., Campbell, J., Newon, J., Melton, J., Salas, E., \& Wilson, K. (2008). Crew resource management training effectiveness: A meta-analysis and some critical needs. International Journal of Aviation Psychology, 18(4), 353-368. http://dx.doi.org/10.1080/10508410802347044

O'Connor, P., Flin, R., Fletcher, G., \& Hemsley, P. (2002). Methods used to evaluate the effectiveness of CRM training: A survey of UK aviation operators. Journal of Human Factors and Aerospace Safety, 2(3), 235-256.

Okray, R., \& Lubnau II, T. (2004). Crew resource management for the fire service. Tulsa, OK: Penn Well Publishers.

Regional Alliance for Firefighter Training. (2015). First annual crew resource management national symposium. Retrieved from http://www.raft911.org/crm/

Risser, D. T., Rice, M. M., Salisbury, M. L., Simon, R., Jay, G. D., \& Berns, S. D. (1999, September). The potential for improved teamwork to reduce medical errors in the emergency department. The MedTeams Research Consortium. Annals of Emergency Medicine, 34(3), 373-383. http://dx.doi.org/10.1016/S0196-0644(99)70134-4

Salas, E., Burke, C. S., Bowers, C. A., \& Wilson, K. A. (2001, Winter). Team training in the skies: Does crew resource management (CRM) training work? Human Factors, 43(4), 641-674. http://dx.doi.org/10.1518/001872001775870386

Salas, E., Fowlkes, J., Stout, R., Milanovich, D. M., \& Prince, C. (1999). Does CRM training improve teamwork skills on the cockpit? Two evaluation studies. The Journal of the Human Factors and Ergonomics Society, 4, 326-343.

http://dx.doi.org/10.1518/001872099779591169 
Salas, E., Prince, C., Bowers, C. A., Stout, R., Oser, R. L., \& Cannon-Bowers, J. A. (1999). A methodology to enhance crew resource management training. Human Factors 41, 161172. http://dx.doi.org/10.1518/001872099779577255

Salas, E., Rhodenizer, L., \& Bowers, C. A. (2000). The design and delivery of crew resource management training: Exploiting available resources. Human Factors, 42(3), 490-511. http://dx.doi.org/10.1518/001872000779698196

Salas, E., Wilson, K. A., Burke, C. S., \& Wightman, D. (2006). Does CRM training work? An update, extension and some critical needs. Human Factors, 48(2), 392-412. http://dx.doi.org/10.1518/001872006777724444

Sexton, J. B., Thomas, E. J., \& Helmreich, R. L. (2000). Error, stress and teamwork in medicine and aviation: Cross sectional surveys. British Medical Journal, 320, 745-749. http://dx.doi.org/10.1136/bmj.320.7237.745

Shortell, S. M., Zimmerman, J. E, Rousseau, D. M., Gillies, R. R., Wagner, D. P., Draper, E. A., . . Duffy, J. (1994, May). The performance of intensive care units: Does good management make a difference? Med Care, 32(5), 508-525. http://dx.doi.org/10.1097/00005650-199405000-00009

Sian, B., Robertson, M., \& Watson, J. (1998). Maintenance resources management handbook. Washington, DC: FAA.

Sundar, E., Sundar, S., Pawlowski, J., Blum, R., Feinstein, D., \& Pratt, S. (2007). Crew resource management and team training. Anesthesiology, 25, 283-300. Retrieved from http://www.medicine.virginia.edu/clinical/departments/anesthesiology/acute/learningmat erials/videos/Crisis-Resource-Managment-Article-2.pdf http://dx.doi.org/10.1016/j.anclin.2007.03.011 
Taylor, J. C. (1998). Evaluating the effects of maintenance resource management (MRM) interventions in airline safety. Washington DC: NTSB - U.S. Office of Aviation Medicine.

Tippett Jr., J. B. (2009, May). From the cockpit to the command post: Crew resource management can improve performance. FireRescue Magazine.

Wakeham, R. T., \& Griffith, J. C. (2015). Unmanned aerial systems in the fire service: Concepts and issues. Proceedings of the Aviation / Aeronautics / Aerospace International Research Conference, Phoenix, AZ. Retrieved from http://commons.erau.edu/cgi/viewcontent.cgi?article=1088\&context=aircon 
Appendix

CRM/TRM Student Interview Questions

1. When is the last time you had CRM/TRM training? What are the key concepts you remember?

2. How was the training implemented? What would you do differently?

3. Have you or someone you worked with used CRM/TRM on the job?

4. Who runs the CRM/TRM training program in your organization?

5. What is your definition of a team? What makes that team effective?

6. Are all suggestions listened to regardless of rank or position?

7. Was there an instance where a new or junior person should have "spoken up" during an emergency situation? Did they? If they did not "speak up", why not?

(Adapted from Halbesleben, Cox, \& Hall, 2011.) 